\title{
PREDICTING THE MICROSTRUCTURE EVOLUTION FOR THE WARM SKEW ROLLING OF BEARING STEEL BALLS UNDER DIFFERENT PROCESS PARAMETERS
}

\author{
NAPOVEDOVANJE RAZVOJA MIKROSTRUKTURE KROGEL IZ \\ LEŽAJNEGA JEKLA, TOPLO POŠEVNO-KOTNO VALJANEGA PRI \\ RAZLIČNIH POGOJIH
}

\author{
Yuanming Huo*, Tao He, Yujia Hu, Wanbo Yang, Menglan Shen \\ School of Mechanical and Automotive Engineering, Shanghai University of Engineering Science, Longteng Road 333, \\ Songjiang District, Shanghai 201620, China
}

Prejem rokopisa - received: 2019-05-16; sprejem za objavo - accepted for publication: 2019-08-18

doi:10.17222/mit.2019.105

\begin{abstract}
The high performance of bearing steel balls (BSBs) depends on the microstructure. Carbide spheroidization is the main mechanism in warm deformation, which leads to the metal flow dynamic softening of bearing steel. Process parameters of warm skew rolling (SR) such as roller angle, rolling temperature and roller rotating speed have a significant influence on the carbide spheroidization of bearing steel. A simulation system of microstructure was developed based on unified visco-plastic constitutive equations to predict the microstructure evolution of BSB during warm SR. Next, a series of FE simulations were conducted to investigate the effect of process parameters of warm SR on the microstructure of BSB. The predicted results show that the degree of carbide spheroidization decreases with the increase of roller angle, rolling temperature and roller rotating speed. The optimal process parameters of warm SR were selected as a roller angle of $2.0^{\circ}$, rolling temperature of $650{ }^{\circ} \mathrm{C}$ and roller rotating speed of $70 \mathrm{~min}^{-1}$. More carbides participation and sufficient carbide spheroidization were achieved under the optimal process parameters of warm SR. The application of optimal process parameters into the formation of BSB with 30 mm diameter can reduce the special carbide spheroidization annealing time and energy consumption, and improve productivity.

Keywords: bearing steel balls, skew rolling, microstructure evolution, carbide spheroidization, process parameters optimization
\end{abstract}

Visoka kakovost krogel iz ležajnega jekla (BSB) je odvisna od njegove mikrostrukture. Sferoidizacija (krogljenje) karbidov je glavni mehanizem, ki poteka med toplo deformacijo, ki povzroča dinamiko mehčanja kovinskega plastičnega toka ležajnega jekla. Procesni parametri toplega poševno-kotnega valjanja (SR), kot so: kot oz. nagib valjarniškega kolesa, njegova hitrost in temperatura valjanja, imajo pomemben vpliv na sferoidizacijo karbidov ležajnega jekla. Avtorji študije so razvili simulacijski model na osnovi poenotenja visoko-plastičnih konstitutivnih enačb za napoved razvoja mikrostrukture BSB med toplim SR. Izvedli so serijo simulacij na osnovi metode končnih elementov (FE), da bi ugotovili vpliv procesnih parametrov na mikrostrukturo toplo poševno-kotno valjanih BSB. Rezultati so pokazali, da se stopnja sferoidizacije karbidov zmanjšuje s povečevanjem nagiba poševnine v valju, njegovo hitrost in temperaturo valjanja. S simulacijo napovedani optimalni procesni parametri toplega SR so bili: kot poševnine $2^{\circ}$, temperatura valjanja $650{ }^{\circ} \mathrm{C}$ in vrtilna hitrost valja $70 \mathrm{~min}^{-1}$. Večji prispevek karbidov in zadovoljiva sferoidizacija karbidov je bila dosežena pri optimalnih pogojih toplega SR. Zaradi uporabe optimalnih procesnih parametrov pri izdelavi BSB premera $30 \mathrm{~mm}$, so lahko skrajšali čas posebnega sferoidizacijskega žarjenja in s tem zmanjšali porabo energije in izboljšali produktivnost.

Ključne besede: krogle iz ležajnega jekla, poševno-kotno valjanje, razvoj mikrostrukture, sferoidizacija karbidov, optimizacija procesnih parametroy

\section{INTRODUCTION}

Cold forging, hot forging, cutting and casting belong to the traditional manufacturing method to produce BSBs. ${ }^{1,2}$ Compared with the traditional manufacturing method, the SR technique has some advantages, such as high production efficiency, saving materials and energy, lower costs, etc. ${ }^{3}$ The formation of BSBs using the SR technique is increasingly becoming the preferred manufacturing method for researchers.

Some publications using the SR technique to form BSB can be found. J. Tomczak et al. ${ }^{4}$ conducted theoretical and experimental research on the formation of balls with a diameter of $30 \mathrm{~mm}$ using the SR technique. Z. Hu

*Corresponding author's e-mail:

yuanming.huo@sues.edu.cn (Yuanming Huo) and Z. Zheng et al. ${ }^{5.6}$ studied the metal flow law of a steel ball using the SR technique, whose roller design method can be adapted to manufacturing the module in this work. Q. Cao and L. Hua et al. ${ }^{7}$ apply the cold SR technique to form BSB, and predict the damage distribution using FE SIMUFACT software. The above publications provide the SR forming method and analysis of the metal flow characteristics in the process of SR. However, the microstructure simulation of BSB formed during warm SR was rarely studied. Particularly, the effect of process parameters of warm SR on the microstructure evolution has not been reported.

The high performance of BSB depends on the microstructure formed in the manufacturing technique. ${ }^{8}$ Process parameters have a significant effect on the microstructure evolution in the manufacturing process. 
The variation of process parameters results in the variation of deformation temperature, deformation rate and stress rate in the manufacturing process. As we expected that microstructure evolved with the variation of these deformation parameters. As for the bearing steel of 52100, the carbide spheroidization mechanism was predominant during the microstructure evolution in the process of warm deformation. ${ }^{9,10}$ The process parameters also have a direct effect on the evolution of dislocation, stress state and carbide spheroidization of the bearing steel during warm SR. Some publications reported the carbide spheroidization mechanism during warm deformation for bearing steel. And, unified visco-plastic constitutive equations were developed to describe the carbide spheroidization mechanism in ${ }^{11}$. However, there is still a lack of a series of FE simulations to optimize the process parameters of warm SR by implementing the unified visco-plastic constitutive equations into the $\mathrm{FE}$ software to develop the FE microstructure predicted system. The optimal process parameters can be used to guide the real manufacturing process.

The aim of this work is to study the effect of process parameters of warm SR on the carbide spheroidization of bearing steel. Firstly, the FE simulation system of the microstructure was developed based on previous unified visco-plastic constitutive equations in ${ }^{11}$. Secondly, a series of FE simulations were carried out by changing the process parameters of warm SR. And, the effects of roller angle, rolling temperature and roller rotating speed on carbide spheroidization were discussed. Finally, optimization of the process parameters and its application in warm SR were carried out.

\section{DEVELOPMENT OF THE MICROSTRUCTURE PREDICTED SYSTEM OF WARM SKEW ROLLING}

The calculated unified visco-plastic constitutive equations of bearing steel 52100 during warm deformation in $^{11}$ were implemented into FE software of Deform-3D via a user routine to develop the microstructure-predicted system of warm SR. It is essential to set up the FE model of warm SR. Two rollers, guide plates and the workpiece were three-dimensional modelled and put into Deform-3D. The detailed spiral cavity of the rollers was designed referring to ${ }^{5}$ so that

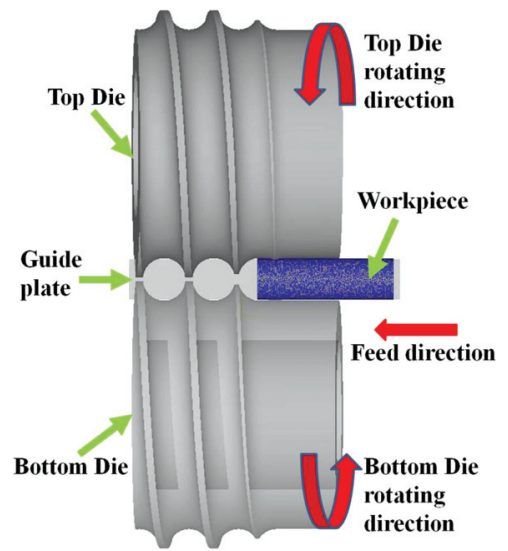

Figure 1: FE model of warm SR3

the process of warm SR for BSB with a diameter of 30 $\mathrm{mm}$ can be predicted. Two rollers and guide plates were assumed as a rigid body. The workpiece was assumed as the uniform and isotropic rigid-plastic body. The shear friction coefficient between the rollers and workpiece was defined as 0.7. Table 1 shows the material property of steel 52100. ${ }^{12,13}$ Table 2 shows the heat conduction and heat capacity. ${ }^{14}$ The heat-transfer coefficient was defined as $40 \mathrm{~N} / \mathrm{s} / \mathrm{mm} /{ }^{\circ} \mathrm{C} .{ }^{15}$

Figure 1 shows the FE model of the warm SR in the software of Deform-3D. The length of the workpiece is $100 \mathrm{~mm}$, and its diameter is $30 \mathrm{~mm}$. The environment temperature is $20^{\circ} \mathrm{C}$. The meshing elements of 100,000 tetrahedrons were used to mesh the workpiece. The time increment is $0.0001 \mathrm{~s}$, and it costs $1.2 \mathrm{~s}$ in the process of warm SR simulation. The two rollers rotate in the same direction.

\section{SIMULATION RESULTS AND DISCUSSION}

As can be seen from ${ }^{16}$ the dual phase $\left(\gamma+\mathrm{Fe}_{3} \mathrm{C}\right)$ can be obtained for the warm deformation temperature range from $650{ }^{\circ} \mathrm{C}$ to $750{ }^{\circ} \mathrm{C}$ for bearing steel 52100. Dislocation proliferates and tangles in the matrix and many precipitated lamellar carbides. The shear stress concentrates within the lamellar carbides, which expedite the break up of the lamellar carbides. A similar globularization phenomenon exists in the deformation process of titanium alloy, whose detailed discussion can be found in ${ }^{17-19}$. When the dislocation density reaches a critical

Table 1: Material properties of steel 52100

\begin{tabular}{|c|c|c|c|c|c|}
\hline $\begin{array}{c}\text { Elasticity modulus } \\
(\mathrm{GPa})\end{array}$ & Poisson's ratio & $\begin{array}{c}\text { Coefficient of } \\
\text { thermal expansion } \\
\left(1 /{ }^{\circ} \mathrm{C}\right)\end{array}$ & $\begin{array}{c}\text { Radiation coefficient } \\
\left(\mathrm{N} / \mathrm{s} / \mathrm{mm} /{ }^{\circ} \mathrm{C}^{4}\right)\end{array}$ & $\begin{array}{c}\text { Convection } \\
\text { coefficient } \\
\left(\mathrm{N} / \mathrm{s} / \mathrm{mm} /{ }^{\circ} \mathrm{C}\right)\end{array}$ & Density $\left(\mathrm{kg} / \mathrm{m}^{3}\right)$ \\
\hline 208 & 0.29 & $1.1 \mathrm{e}-05$ & 0.8 & 0.02 & 7810 \\
\hline
\end{tabular}

Table 2: Heat conduction and heat capacity of steel 52100

\begin{tabular}{|l|c|c|c|c|c|c|c|c|c|c|}
\hline \multicolumn{1}{|c|}{ Temperatures $\left({ }^{\circ} \mathrm{C}\right)$} & 100 & 200 & 300 & 400 & 500 & 600 & 700 & 800 & 900 & 1000 \\
\hline Coefficient of heat conduction $\left(\mathrm{W} /\left(\mathrm{m} \cdot{ }^{\circ} \mathrm{C}\right)\right)$ & 41 & 41 & 39.9 & 38.1 & 35.9 & 33.6 & 33.6 & 33.6 & 33.6 & 33.6 \\
\hline Heat capacity $\left(\mathrm{J} / \mathrm{kg} /{ }^{\circ} \mathrm{C}\right)$ & 371 & 451 & 461 & 496 & 533 & 568 & 611 & 677 & 787 & 787 \\
\hline
\end{tabular}


value, lamellar carbides were transformed into the spheroidized microstructure in the warm forming. Moreover, metal flow softening was induced by carbide spheroidization in the warm forming of bearing steel. Therefore, carbide spheroidization and dislocation evolution are the main physical evolution mechanism for bearing steel during the warm rolling.

The evolution of the carbide spheroidization is dependent on the basic deformation parameters of strain, deformation temperature, strain rates and stress state. The main process parameters of the warm SR such as roller angle, rolling temperature and roller rotating speed have a direct relationship with the basic deformation parameters. Therefore, it is important to investigate the effect of the process parameters of warm SR on the carbide spheroidization by comparing the simulation results under different process parameters. Table 3 shows the simulation programs under different process parameters of warm SR for BSB.

Table 3: Simulation programs under different process parameters of warm SR

\begin{tabular}{|c|c|c|c|}
\hline No. & Roller angle & $\begin{array}{c}\text { Rolling } \\
\text { temperature }\end{array}$ & $\begin{array}{c}\text { Roller rotating } \\
\text { speed }\end{array}$ \\
\hline 1 & 2.0 & 750 & 110 \\
\hline 2 & 2.5 & 750 & 110 \\
\hline 3 & 3.0 & 750 & 110 \\
\hline 4 & 2.5 & 700 & 110 \\
\hline 5 & 2.5 & 650 & 110 \\
\hline 6 & 2.5 & 750 & 90 \\
\hline 7 & 2.5 & 750 & 70 \\
\hline
\end{tabular}

\subsection{Effect of roller angle on the carbide spheroidiza- tion}

The prerequisite of carbide spheroidization is carbide precipitation during the phase transformation during warm deformation for bearing steel. Figure 2 shows the distribution of phase transformation fraction in the longitudinal section of $\mathrm{BSB}$ at a rolling temperature of

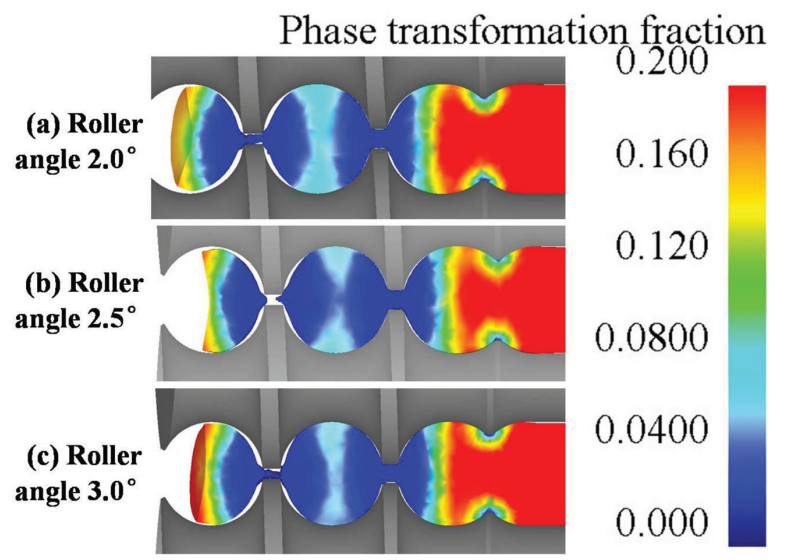

Figure 2: Distribution of the phase transformation fraction in the longitudinal section of the BSB at a rolling temperature of $750{ }^{\circ} \mathrm{C}$ and a roller rotating speed of $110 \mathrm{~min}^{-1}$
$750{ }^{\circ} \mathrm{C}$ and roller rotating speed of $110 \mathrm{~min}^{-1}$. It can be seen from Figure 2 that the phase-transformation fraction decreases with the increases of the roller angle. Carbide phase transformation is the most at a roller angle of $2.0^{\circ}$. When the roller angle is $3.0^{\circ}$, the carbide phase transformation is the minimum. The amount of precipitation under a roller angle of $2.5^{\circ}$ is more than that under a roller angle of $3.0^{\circ}$, but less than that under a roller angle of $2.0^{\circ}$. In addition, carbide precipitation concentrates on the equator of the BSB. The two ends of the BSB have no phase transformation. The carbide phase transformation depends on the temperatures and the time. Due to this there is a short time of $1.2 \mathrm{~s}$ during $\mathrm{SR}$, and temperature is the key factor for the carbide precipitation. The maximum plastic deformation occurs at the two ends of the BSB. The plastic temperature rise leads the carbide to dissolve in two ends of the BSB. Conversely, the deformation amount of the equator is less than that of two ends. The, temperature decreases in the equator because of the contact heat dissipation with two rollers. Therefore, carbide precipitation concentrates on the equator of the BSB.

Figure 3 shows the distribution of the carbide spheroidization fraction in the longitudinal section of the BSB at a rolling temperature of $750{ }^{\circ} \mathrm{C}$ and a roller rotating speed of $110 \mathrm{~min}^{-1}$. It can be seen from Figure 3 that the carbide spheroidization fraction is 0.6 in the heart of the BSB. The carbide spheroidization fraction reaches 0.99 in the part from outer surface to some certain thickness within the BSB. Comparing with Figure 3a to 3c, it is clear that there is no sufficient carbide spheroidization in the heart of the BSB, especially at the roller angle of $2.0^{\circ}$.

When the roller angle is $2.0^{\circ}$, the phase-transformation fraction is the highest shown in Figure 2, but its carbide spheroidization fraction is the lowest, shown in Figure 3. Because the precondition of carbide spheroidization is cementite precipitation, the multiplication term $F_{\mathrm{c}} \cdot W$ between the phase-transformation fraction and the carbides-spheroidization fraction was defined as the

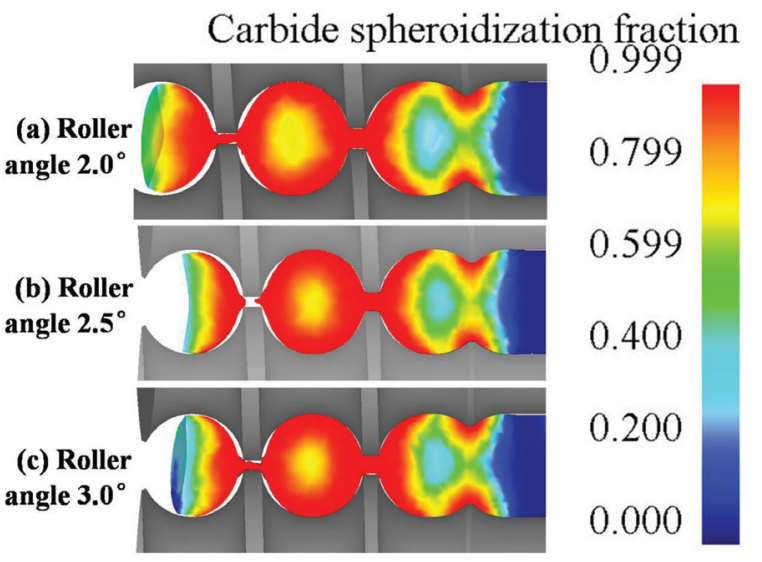

Figure 3: Distribution of carbide spheroidization fraction in the longitudinal section of the BSB at a rolling temperature of $750{ }^{\circ} \mathrm{C}$ and a roller rotating speed of $110 \mathrm{~min}^{-1}$ 


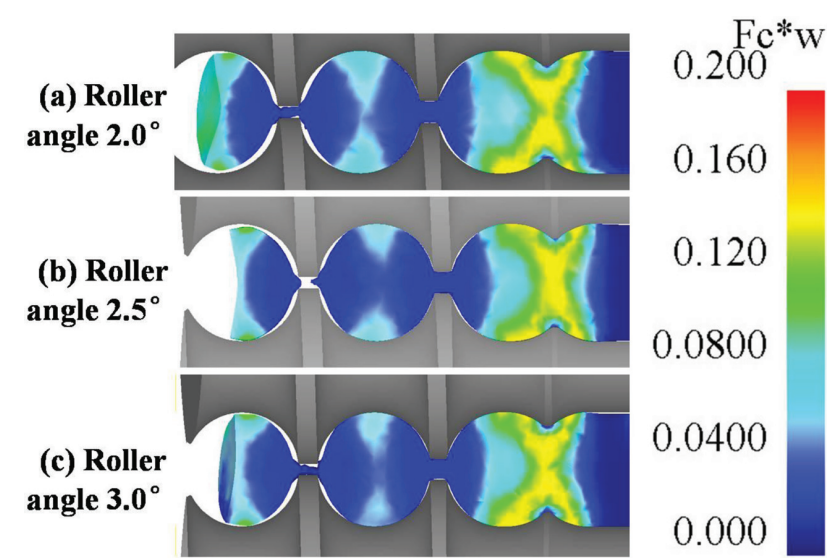

Figure 4: Distribution of multiplication term between phase-transformation fraction and carbide-spheroidization fraction in the longitudinal section of the BSB at a rolling temperature of $750{ }^{\circ} \mathrm{C}$ and a roller rotating speed of $110 \mathrm{~min}^{-1}$

evaluation criterion in this work, to objectively evaluate the degree of carbides spheroidization of BSB.

Figure 4 shows the distribution of the multiplication term between the phase-transformation fraction and the carbide-spheroidization fraction in the longitudinal section of the BSB at a rolling temperature of $750{ }^{\circ} \mathrm{C}$ and roller rotating speed of $110 \mathrm{~min}^{-1}$. It can be seen that the degree of carbides spheroidization of BSB is the highest when the roller angle is $2.0^{\circ}$ by comparing Figure 4a to $\mathbf{4 c}$. The degree of carbides spheroidization of the BSB is the lowest when the roller angle is $3.0^{\circ}$. The degree of carbides spheroidization of the equator is the most obvious. However, the degree of carbides spheroidization is the least in the heart and two ends of BSB. Therefore, the degree of carbides spheroidization decreases with the increase of the roller angle.

\subsection{Effect of rolling temperature on the carbide spheroidization}

Figure 5 shows the distribution of the phase-transformation fraction in the longitudinal section of the BSB at a roller angle of $2.5^{\circ}$ and a roller rotating speed of $110 \mathrm{~min}^{-1}$. It can be seen from Figure 5 that the phase-transformation fraction decreases with the increases of the rolling temperature. The phase-transformation fraction is the most at the rolling temperature of $650{ }^{\circ} \mathrm{C}$, and that it is the least at the rolling temperature of $750{ }^{\circ} \mathrm{C}$. The phase-transformation fraction at the rolling temperature of $700{ }^{\circ} \mathrm{C}$ is higher than that at rolling temperature of $750{ }^{\circ} \mathrm{C}$, but lower than that at rolling temperature of $650{ }^{\circ} \mathrm{C}$. Carbide precipitation concentrates on the equator, and there is the least at the two ends of the BSB. The phase-transformation fraction is related to the temperature. The plastic temperature rise is higher at the two ends of the BSB due to the largest deformation. Contacting heat dissipation leads to a decrease of the temperature at the equator of the BSB.

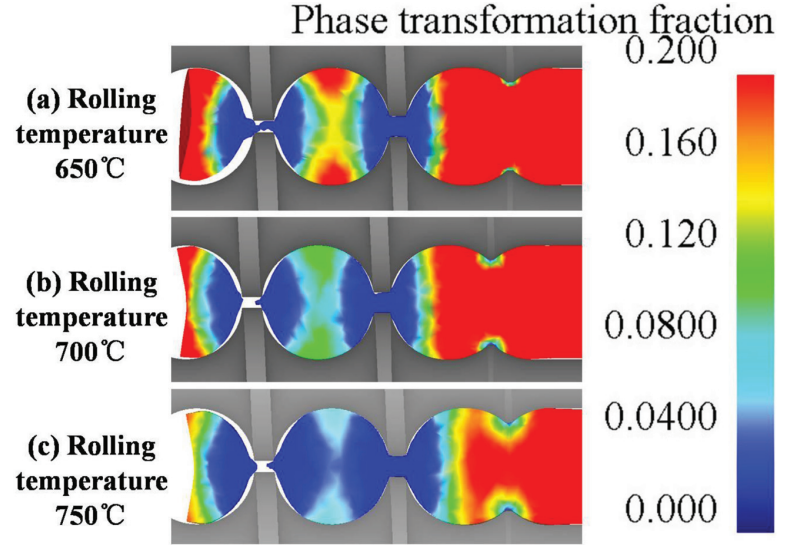

Figure 5: Distribution of the phase transformation fraction in the longitudinal section of the BSB at a roller angle of $2.5^{\circ}$ and a roller rotating speed of $110 \mathrm{~min}^{-1}$

Figure 6 shows the distribution of the carbide spheroidization fraction in the longitudinal section of the $\mathrm{BSB}$ at a roller angle of $2.5^{\circ}$ and a roller rotating speed of $110 \mathrm{~min}^{-1}$. It can be seen from Figure 6 that the rolling temperature has a significant influence on the carbide spheroidization. When the rolling temperature is $650{ }^{\circ} \mathrm{C}$, the carbide spheroidization fraction reaches 0.999 in the outer sphere of BSB, and the carbide spheroidization fraction reaches 0.5 in the heart of the $\mathrm{BSB}$. When the rolling temperature is $700{ }^{\circ} \mathrm{C}$, the thickness increases for the carbide spheroidization fraction of 0.999 , and the carbide spheroidization fraction reaches about 0.6 in the heart of the BSB. When the rolling temperature is $750{ }^{\circ} \mathrm{C}$, the thickness of the carbide spheroidization fraction of 0.999 is greater than that at the rolling temperature of $700{ }^{\circ} \mathrm{C}$. Therefore, the carbide-spheroidization fraction increases with the increase of the rolling temperature.

Figure 7shows the distribution of the multiplication term between the phase-transformation fraction and the carbide-spheroidization fraction in the longitudinal section of the BSB at a roller angle of $2.5^{\circ}$ and a roller

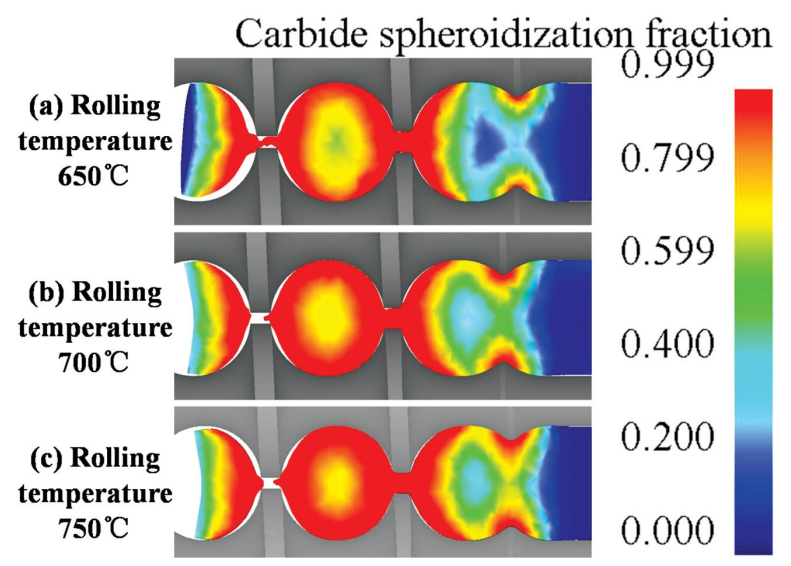

Figure 6: Distribution of carbide spheroidization fraction in the longitudinal section of the BSB at a roller angle of $2.5^{\circ}$ and a roller rotating speed of $110 \mathrm{~min}^{-1}$ 


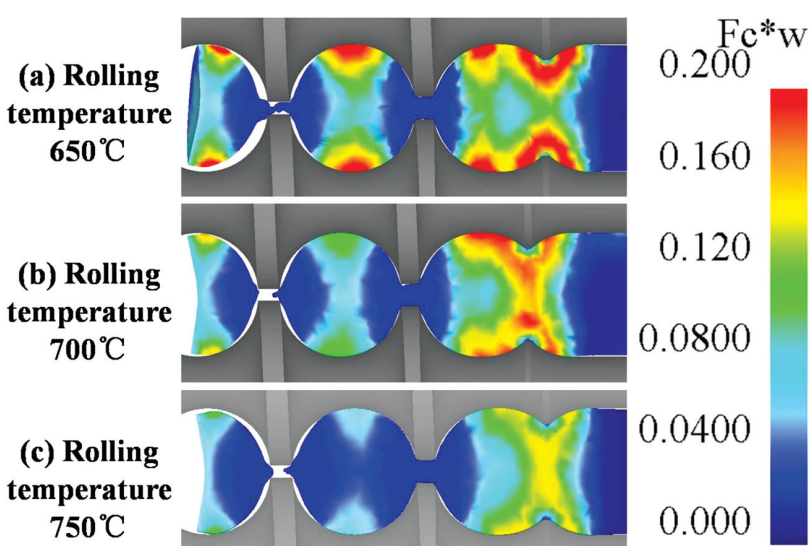

Figure 7: Distribution of multiplication term between the phase-transformation fraction and the carbide-spheroidization fraction in the longitudinal section of the BSB at a roller angle of $2.5^{\circ}$ and a roller rotating speed of $110 \mathrm{~min}^{-1}$

rotating speed of $110 \mathrm{~min}^{-1}$. It can be seen from Figure 7 that the multiplication term increases with the decrease of the rolling temperature. The multiplication term is the largest at the rolling temperature of $650{ }^{\circ} \mathrm{C}$, which concentrates at the equator of the BSB. When the rolling temperature is $700{ }^{\circ} \mathrm{C}$, the multiplication term is lower than that at the rolling temperature of $650{ }^{\circ} \mathrm{C}$, which is located in the equatorial band. When the rolling temperature is $750{ }^{\circ} \mathrm{C}$, the multiplication term is the lowest, and the value is almost zero in the heart and two ends of the BSB. Therefore, the degree of carbide spheroidization decreases with the increase of the rolling temperature.

\subsection{Effect of roller rotating speed on the carbide spheroidization}

Figure 8 shows the distribution of the phase-transformation fraction in the longitudinal section of the BSB at a roller angle of $2.5^{\circ}$ and a rolling temperature of $750{ }^{\circ} \mathrm{C}$. It can be seen from Figure 8 that the phasetransformation fraction decreases with the increase of the roller rotating speed. There is almost no carbide precipitation at the two ends of the BSB. The phase-transformation fraction is higher at the equator and the heart of BSB. That is because the higher temperature distributes at the two ends, and there is a lower temperature in the equator and the heart of the BSB. When the roller rotating speed is $70 \mathrm{~min}^{-1}$, the phase-transformation fraction is the most, and the value reaches 0.12 in the equator and the heart of the BSB. When the roller rotating speed is $90 \mathrm{~min}^{-1}$, the phase-transformation fraction is lower than that at the roller rotating speed of $70 \mathrm{~min}^{-1}$. The phase-transformation fraction reaches 0.12 in the equator of BSB, and its value is only 0.08 at the heart of the BSB. When the roller rotating speed is 110 $\mathrm{min}^{-1}$, the phase-transformation fraction is the least, the value mainly concentrates in the belt of equator. A larger roller rotating speed means the plastic deformation rate

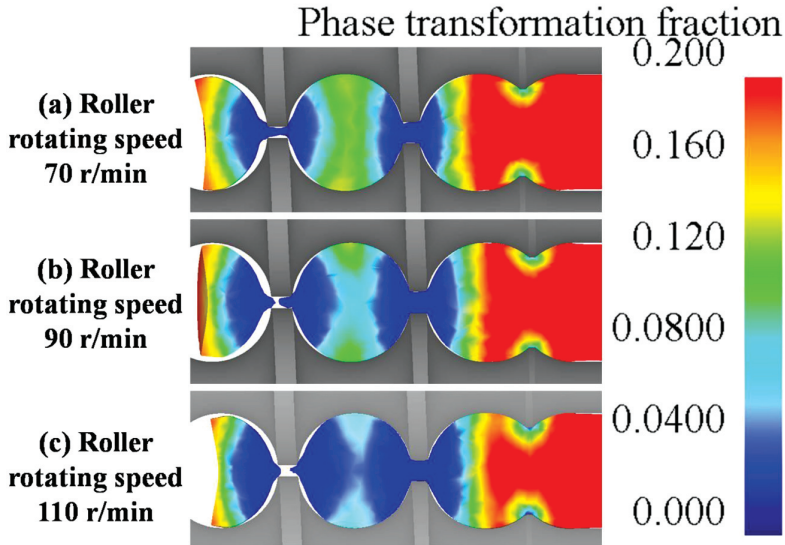

Figure 8: Distribution of the phase-transformation fraction in the longitudinal section of the BSB at a roller angle of $2.5^{\circ}$ and a rolling temperature of $750{ }^{\circ} \mathrm{C}$

is higher, which leads to an increase of the temperature due to plastic deformation. The precipitated carbides easily dissolve at higher temperature. Therefore, the phase-transformation fraction is lower at the higher roller rotating speed.

Figure 9 shows the distribution of the carbidespheroidization fraction in the longitudinal section of the a BSB at roller angle of $2.5^{\circ}$ and a rolling temperature of $750{ }^{\circ} \mathrm{C}$. It can be seen from Figure 9 that the carbide spheroidization fraction is higher in the range from out of the surface to some deep distance. The carbidespheroidization fraction is relatively lower in the heart of the BSB. When the roller rotating speed is $70 \mathrm{~min}^{-1}$, the carbide spheroidization fraction is about 0.5 in the heart of BSB, whose occupied volume also is relatively larger. When the roller rotating speed is $90 \mathrm{~min}^{-1}$, the carbidespheroidization fraction is about 0.6 in the heart of the $\mathrm{BSB}$. When the roller rotating speed is $110 \mathrm{~min}^{-1}$, the carbide spheroidization fraction is about 0.6 in the heart of BSB. However, the thickness is greater for the value of 0.999 than that at the roller rotating speed is $90 \mathrm{~min}^{-1}$.

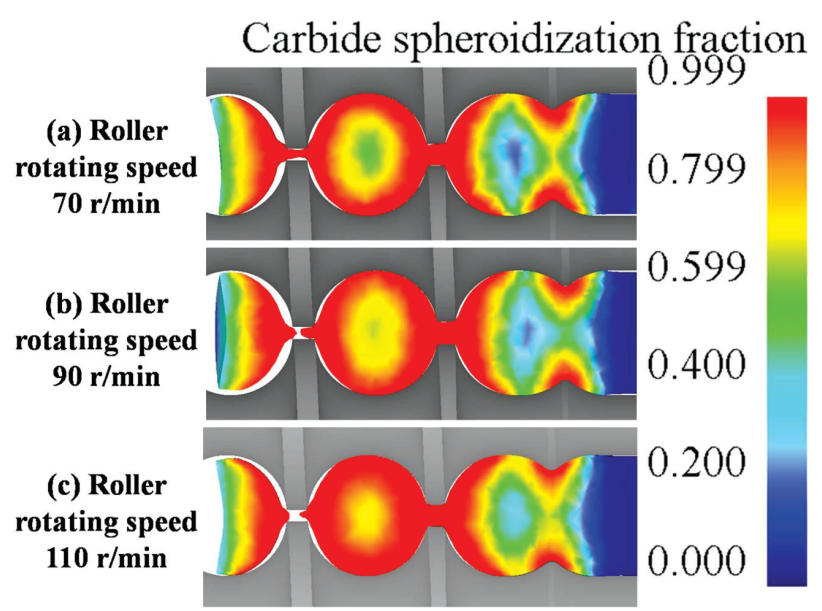

Figure 9: Distribution of carbide-spheroidization fraction in the longitudinal section of the BSB at a roller angle of $2.5^{\circ}$ and a rolling temperature of $750{ }^{\circ} \mathrm{C}$ 


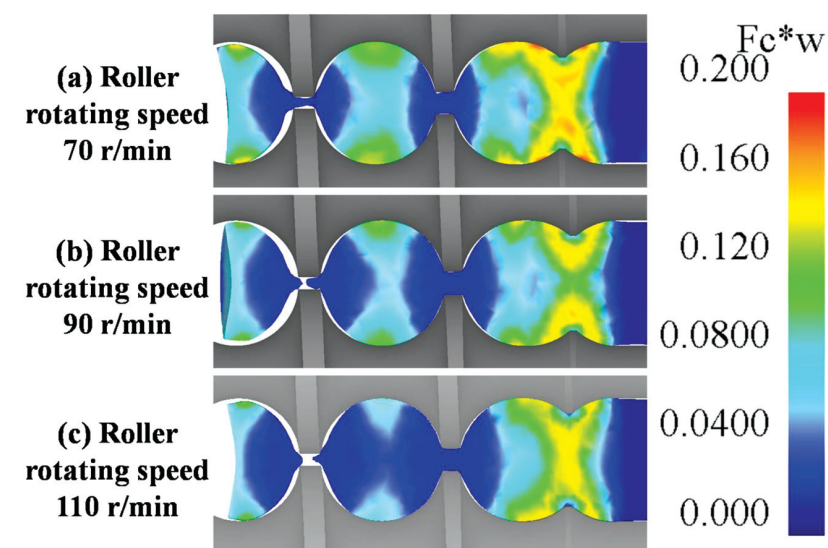

Figure 10: Distribution of the multiplication term between the phase-transformation fraction and the carbide-spheroidization fraction in the longitudinal section of the BSB at a roller angle of $2.5^{\circ}$ and a rolling temperature of $750{ }^{\circ} \mathrm{C}$

Therefore, the carbide spheroidization fraction increases with the increase of the roller rotating speed.

Figure 10 shows the distribution of the multiplication term between the phase-transformation fraction and the carbide-spheroidization fraction in the longitudinal section of the BSB at a roller angle of $2.5^{\circ}$ and a rolling temperature of $750{ }^{\circ} \mathrm{C}$. It can be seen from Figure 10 that the multiplication term decreases with the increase of the roller rotating speed. When the roller rotating speed is $70 \mathrm{~min}^{-1}$, the value of the multiplication term is the largest, i.e., 0.12 . The carbide spheroidization mainly distributes in the equator and the heart of the BSB. When the roller rotating speed is $90 \mathrm{~min}^{-1}$, the value of the multiplication term is lower than that when the roller rotating speed is $70 \mathrm{~min}^{-1}$. The volume of the carbide spheroidization decreases in the equator and the heart of the BSB. When the roller rotating speed is $110 \mathrm{~min}^{-1}$, the value of the multiplication term is the smallest. The carbide spheroidization only distributes in the equator of the BSB, whose value is about 0.06 . There is almost no carbide spheroidization at the two ends of the BSB. Therefore, the degree of carbide spheroidization decreases with an increase of the roller rotating speed.

\subsection{Optimization of the process parameters and the application}

The optimal process parameters for warm SR were selected by investigating the effect of the roller angle, the rolling temperature and the roller rotating speed on the carbide spheroidization, such as the roller angle of $2.0^{\circ}$, the rolling temperature of $650{ }^{\circ} \mathrm{C}$ and the roller rotating speed of $70 \mathrm{~min}^{-1}$. The selected process parameters for the warm SR were applied to predict the distribution of the phase-transformation fraction, the carbide spheroidization fraction and its multiplication term within the BSB of $30 \mathrm{~mm}$ diameter during the warm SR.

Figure 11 shows the distribution of the phase-transformation fraction, the carbide-spheroidization fraction (a)

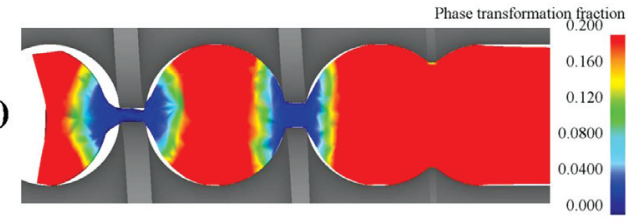

Carbide spheroidization fraction

(b)

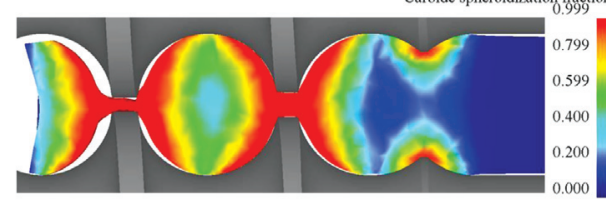

(c)

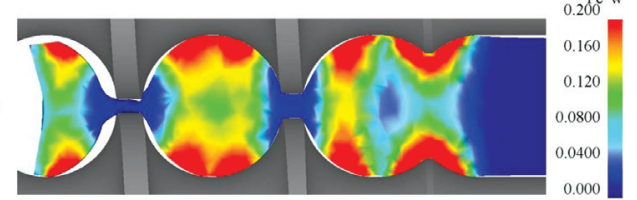

Figure 11: Distribution of:a) phase-transformation fraction, b) carbide-spheroidization fraction and c) multiplication term between phase-transformation fraction and carbide-spheroidization fraction in the longitudinal section of BSB at a roller angle of $2.0^{\circ}$ and a rolling temperature of $650{ }^{\circ} \mathrm{C}$ with a roller rotating speed of $70 \mathrm{~min}^{-1}$

and its multiplication term in the longitudinal section of the BSB at a roller angle of $2.0^{\circ}$ and a rolling temperature of $650{ }^{\circ} \mathrm{C}$ with a roller rotating speed of $70 \mathrm{~min}^{-1}$. It can be seen from Figure 11a that the phase-transformation fraction reaches about 0.2, which uniformly distributes in all areas except for a small part of the two ends. The phase transformation depends on the rolling temperature. The lower rolling temperature ensures the carbide participation within the BSB. However, carbide spheroidization was determined by the deformation degree and the deformation rate. Those two deformation parameters were larger at the two ends of BSB, but smaller in the equator and the heart of BSB. Therefore, the carbide spheroidization fraction is higher at the two ends, whose value reaches 0.999 . The carbide-spheroidization fraction is the relative lower value of 0.6 in the equator and heart of the BSB, shown in Figure $\mathbf{1 1 b}$. Figure 11c shows the value of the multiplication term is the highest, i.e., above 0.2 . In the heart of the BSB, the value of the multiplication term is about 0.12 . However, the value of multiplication term is the lowest in the small part of the two ends, i.e., below 0.04.

From the above analysis it can be concluded that more carbide participation and sufficient carbide spheroidization were achieved under the optimal process parameters of warm SR. The application of the optimal process parameters into the formation of BSB of $30 \mathrm{~mm}$ diameter can reduce the special spheroidizing annealing time and energy consumption, and improve productivity.

\section{CONCLUSIONS}

Carbide spheroidization predominates during the microstructure evolution for the warm deformation of bearing steel. In order to obtain the high performance of 
bearing steel balls, a warm skew rolling technique was adopted to form bearing steel in this work. The process parameters have a great influence on the carbide spheroidization of bearing steel. It is vital to search for the optimal process parameters of warm skew rolling using a FE simulation. A series of FE simulations were conducted using the developed constitutive model to compare the microstructure distribution of the steel bearing balls under the different skew rolling conditions. Some detailed conclusions were summarized:

A set of unified visco-plastic constitutive equations of bearing steel 52100 during warm deformation were implemented into FE software of Deform-3D via a user routine to develop the microstructure predicted system of warm SR. A series of FE simulations were conducted using the microstructure predicted system to investigate the effect of the roller angle, rolling temperature and roller rotating speed of warm SR on carbide spheroidization.

Phase-transformation fraction decreases with the increases of the roller angle. Carbide precipitation concentrates on the equator of the BSB. Carbide spheroidization fraction increases with the increase of the roller angle. The degree of carbide spheroidization decreases with the increase of the roller angle.

Phase-transformation fraction decreases with the increases of the rolling temperature. Carbide precipitation concentrates on the equator, and it is the least at the two ends of the BSB. The carbide spheroidization fraction increases with the increase of the rolling temperature. The degree of carbide spheroidization decreases with the increase of the rolling temperature.

Phase-transformation fraction decreases with the increases of the roller rotating speed. The carbidespheroidization fraction increases with the increase of the roller rotating speed. The degree of carbide spheroidization decreases with the increase of the roller rotating speed.

The optimal process parameters for warm SR were selected as roller angle of $2.0^{\circ}$, a rolling temperature of $650{ }^{\circ} \mathrm{C}$ and a roller rotating speed of $70 \mathrm{~min}^{-1}$. More carbides participation and sufficient carbide spheroidization were achieved under the optimal process parameters of warm SR. The application of optimal process parameters into the formation of BSB with $30 \mathrm{~mm}$ diameter can reduce the special spheroidizing annealing time and energy consumption, and the improve productivity.

\section{Acknowledgments}

This project is funded by the National Natural Science Foundation of China (Grant No. 51805314), National Key Research and Development Program of China (Grant No. 2018YFB1307900), Shanghai Science and Technology Commission (Grant No. 16030501200), Shanghai University of Engineering and Science (Grant No. E3-0903-17-01006 \& No. E3-0501-18-01002). The Robot Functional Materials Preparation Laboratory in Shanghai University of Engineering Science is also gratefully acknowledged.

\section{REFERENCES}

${ }^{1}$ T. He, Y. Huo, A New Damage Evolution Model for Cold Forging of Bearing Steel-Balls, Transactions of the Indian Institute of Metals, (2017) 1-9

${ }^{2}$ J. Tomczak, Z. Pater, T. Bulzak, Designing of screw impressions in the helical rolling of balls, Archives of Civil \& Mechanical Engineering, 14 (2014) 104-113

${ }^{3}$ F. L. Mao, Y. H. Shuang, Q. H. Wang, F. J. Wang, Y. J. Gou, C. J. Zhao, Theoretical and Experimental Study of the Tandem Skew Rolling Process, Steel Research International, (2018)

${ }^{4}$ J. Tomczak, Z. Pater, J. Bartnicki, Skrew Rolling of Balls in Multiple Helical Impressions, Archives of Metallurgy \& Materials, 58 (2013) 1071-1076

${ }^{5}$ Z. H. Zheng, B. Y. Wang, H. U. Zheng-Huan, Metal flow law of steel ball forming by skew rolling, Chinese Journal of Engineering, (2015)

${ }^{6}$ H. Zhenghuan, W. Baoyu, Z. Zhenhua, Research and industrialization of near-net rolling technology used in shaft parts, Frontiers of Mechanical Engineering, 13 (2018) 17-24

${ }^{7}$ C. Qiang, H. Lin, D. S. Qian, Finite element analysis of deformation characteristics in cold helical rolling of bearing steel-balls, Journal of Central South University: English Version, 22 (2015) 1175-1183

${ }^{8}$ H. K. D. H. Bhadeshia, Steels for bearings, Progress in Materials Science, 57 (2012) 268-435

${ }^{9}$ Y. Huo, H. Tao, S. Chen, R. Wu, Mechanical Behavior and Microstructure Evolution of Bearing Steel 52100 During Warm Compression, JOM, 70 (2018) 1112-1117

${ }^{10}$ G. H. Zhu, G. Zheng, Directly spheroidizing during hot deformation in GCr15 steels, Frontiers of Materials Science in China

${ }^{11}$ T. He, Y. Huo, X. Shi, S. Chen, Modeling of Carbide Spheroidization Mechanism of 52100 Bearing Steel Under Warm Forming Conditions, Metallurgical and Materials Transactions A, (2019)

${ }^{12} \mathrm{X}$. Xu, FE simulation of steel balls during cold heading, in, Harbin Institute of Technology, 2011

${ }^{13} \mathrm{X}$. Hua, Study on optimization of cold upsetting of steel ball, in, Jiangnan University, 2011

${ }^{14} \mathrm{~W}$. Chi, Study on controlled rolling and cooling technology of bearing steel rod wire rolling, in, Shanghai Jiaotong University, 2009

${ }^{15} \mathrm{~W}$. Xiao, Process technology and equipment design of skew rolling for producing ball milling steel balls with diameter of $100 \mathrm{~mm}$, in, University of Science and Technology Beijing, 2014

${ }^{16}$ Y. Huo, T. He, S. chen, R. Wu, Mechanical Behavior and Microstructure Evolution of Bearing Steel 52100 During Warm Compression, JOM, 2018

${ }^{17}$ J. Luo, P. Ye, W. Han, M. Li, Collaborative behavior in $\alpha$ lamellae and $\beta$ phase evolution and its effect on the globularization of TC17 alloy, Materials \& Design, 2018

${ }^{18}$ K. Wang, W. Zeng, Y. Zhao, Y. Lai, Y. Zhou, Dynamic globularization kinetics during hot working of Ti-17 alloy with initial lamellar microstructure, Materials Science and Engineering: A, 2010

${ }^{19}$ L. Li, M. Li, Evolution characterization of $\alpha$ lamellae during isothermal compression of TC17 alloy with colony- $\alpha$ microstructure, Materials Science and Engineering, A 712 (2018) 637-644 